\title{
Financial Compensations for Losses Due to Bovine Spongiform Encephalopathy in the Czech Republic in 2001-2007
}

\author{
R. POSPÍŠIL ${ }^{1}$, Z. POSPÍŠIL ${ }^{2}$, D. ZENDULKOVÁ ${ }^{2}$, P. LÁNY ${ }^{2}$ \\ ${ }^{1}$ Palacky University, Olomouc, Czech Republic \\ ${ }^{2}$ University of Veterinary and Pharmaceutical Sciences, Brno, Czech Republic
}

Received December 17, 2007
Accepted April 14, 2008

\begin{abstract}
Pospíšil R., Z. Pospíšil, D. Zendulková, P. Lány: Financial Compensations for Losses Due to Bovine Spongiform Encephalopathy in the Czech Republic in 2001-2007. Acta Vet. Brno 2008, 77: 475-482.

Based on Czech legislature, the farmers whose herds were affected by bovine spongiform encephalopathy (BSE) are reimbursed for the costs associated with disease diagnosis, killing the animals and safely disposing of their carcasses, decontamination of their premises, if necessary, and compensations for the value of the animals killed and for losses due to non-materialised production. Between 2001 and 2007, a total of 1,194,743 were examined for BSE, 27 BSEpositive cases were detected and, consequently, 3,997 animals were killed and destroyed. To reduce the negative economic impact on agricultural production, farmers were compensated for selected cost items by the Ministry of Finance of the Czech Republic from the state budget. The costs of examination for BSE, killing of animals and destroying their carcasses, and decontamination of farms were CZK 18.9 million (9.7\%), compensations for the value of the animals killed amounted to almost CZK 164.0 million (83.3\%) and compensations for nonmaterialised production reached almost CZK 13.6 million (6.9\%). Together with some additional costs, the total of reimbursements during the period of 2001-2007 in the Czech Republic was almost CZK 197 million. These results are discussed in comparison to rather scarce data in the international literature which reports only the total costs associated with BSE occurrence and not individual cost items by which cattle and beef producers are burdened.
\end{abstract}

Financial compensation, bovine spongiform encephalopathy, cattle, infectious diseases, costs, financial law

A single outbreak of bovine spongiform encephalopathy (BSE) in 2007 confirms that, in the Czech Republic, the disease incidence has a decreasing trend, which is in agreement with the situation in other EU countries. The regular examination of animals known as active monitoring came into effect on February 1, 2001, and by November 30, 2007 a total of 1.194 .743 cattle were examined, of which 27 animals tested positive (Duben 2007). The first two cases of BSE were detected in 2001, other two cases in 2002, four in 2003, seven in 2004 and eight in 2005; in 2006 BSE incidence declined and only three diseased animals were recorded. The last case of BSE was identified in September 2007 (Saksún 2007).

Of the 27 BSE infected animals, 11 were identified by regular monitoring of cows older than 30 months at slaughter, nine at emergency slaughter, six were fallen stock and one was a cohort-derived animal. The average number of cattle lost to death due to BSE annually was 3.86 animals, at an average age of 68 months, in seven years. The highest BSE incidence, which was five animals, was in the Central Bohemian and Pardubice regions, four BSEpositive animals were in each of the regions of Vysočina, South Bohemia and Liberec, two animals were recorded in the South Moravian region, and the Hradec Králové, Zlín and North Moravia regions had one infected animal each. The remaining regions (Olomouc, Karlovy Vary, Plzeň, Ústí nad Labem and Prague) were BSE-free (Meloun 2006).

Veterinary monitoring provided evidence supporting the often-discussed issue that it is

Address for correspondence:

Ing. Richard Pospíšil, Ph.D.

Palacky University

Department of Financial Law and Economics

tř. 17.listopadu č. 8, Olomouc

77111 Czech Republic

Phone: +420585637628

$+420732285453$

E-mail: richard.pospisil@upol.cz

http://www.vfu.cz/acta-vet/actavet.htm 
necessary to kill all animals in a cohort for the largest possible detection of BSE. This necessity was definitely shown by finding another, the $23^{\text {rd }}$ BSE-positive animal in the $22^{\text {nd }}$ cohort involving 34 animals (Duben 2007). A cohort is defined as a group of bovine animals which includes both: (i) animals born in the same herd as the affected bovine animal, and within 12 months preceding or following the date of birth of the affected bovine animal; and (ii) animals that at any time during the first year of their lives were reared together with the affected bovine animal during the first year of its life and kept on the same sort of feed that was also fed to the affected animal. Offspring of the affected animal is also included (Anonymous 2003).

The cohorts slaughtered in the Czech Republic between 2001 and 2007 ranged in size from three to 875 animals (average cohort size was 148 animals). As a result of 27 positive BSE findings, a total of 3,997 cows were killed and their carcasses were destroyed.

In accordance with its Common Agricultural Policy and farming promotion, the EU provides financial compensations to farmers who have suffered losses due to BSE. Their allocation is regulated by "Act No. 166/1999 on Veterinary Care and on Amendment of Certain Related Acts" (Veterinary Act), with particulars given in Title IX "Compensation of Costs and Losses Incurred in Connection with Dangerous Contagious Diseases". This defines reimbursements to farmers whose cattle herds have been affected by the transmissible diseases specified in Annexes 3 and 4 to this Act. For 62 specified dangerous transmissible diseases, it outlines indemnity strategies and general itemisation of the compensation (Anonymous 1999). The Czech legislation is in full agreement with the Regulation (EC) No 999/2001 of the European Parliament and of the Council, of May 22, 2001, laying down rules for the prevention, control and eradication of certain transmissible spongiform encephalopathies, as amendment.

To provide a deeper insight into legal and economic aspects associated with BSE in the Czech Republic, the aim of our study was, in the first part, to select and comment on the general provisions of the Veterinary Act that are relevant to BSE occurrence, because no studies evaluating economic losses due to BSE in the Czech Republic have so far been published and information available in the international literature is mainly concerned with total costs per given period without any detailed analysis and cost specification, the second part is focused on the evaluation of indemnity policy and quantification of reimbursements provided to farmers according to the Veterinary Act in the period from 2001 to 2007. The total costs were itemised and the cost items broken down to cover individual operations the farmers were responsible for in BSE management and for which they were subsequently reimbursed.

\section{Materials and Methods}

The chief method used in the first part was the evaluation of legal rules, i.e., acts, regulations and implementing provisions, and their application to BSE occurrence in Czech herds. In addition, the EU legislation concerning this issue was analysed and compared with the relevant legislation of the Czech Republic.

The method for economic evaluation in the second part was the analysis of statistical data related to the costs of BSE eradication in the Czech Republic; this information was provided by the Ministry of Agriculture of the Czech Republic (Saksún 2007). Subsequently, the data were related to individual cost compensation items, as specified by the Veterinary Act, as follows:

Compensation for direct costs involved killing the infected animal and safe disposal of its carcass, including its transport to a rendering plant, or transport of a living animal from a cohort to that plant.

Compensation for costs related to killing and disposal involved wages and salaries, expert's report, transport of workers, veterinary medical services, transportation within the farm, and decontamination of the holding in case slaughter was performed in the cow house.

Compensation for production that could not be materialised included losses related to meat and dairy production, costs of fertilisers, and the value of animals confiscated at an abattoir. In dairy cows compensations were provided for the highest milk yield as defined by the "Milk Yield Assessment". In each lactating cow, the number of days remaining to the standard 305-day lactation period was multiplied by the cow's average milk yield to calculate the value of non-materialized milk production.

The compensation for costs of emergency regulations observance involved the costs of killing and destroying 
animals not included in the cohort, but spent during the period the Emergency Veterinary Regulations were imposed or when transport of animals among farms was banned.

\section{Results}

Part I. Legal background for indemnity policy

The general itemisation of compensations and principles of their allocation are defined by the Veterinary Act (No. 166/1999 Coll.) in Title IX, Articles 67 to 70. The items relevant to BSE occurrence are described and explained below:

Article 67, paragraph (1) states that the farmer will obtain a compensation of the costs and losses suffered due to emergency veterinary measures imposed in order to eradicate and prevent the spread of any of the dangerous contagious diseases listed in Annexes 3 and 4 to this Act, on condition that these measures at least include the quarantine of animals on the holding and ban on their transfer from the time of a suspicion to the time of a confirmation of the disease occurrence.

The general principles of compensation for the costs and losses defined above are specified in paragraph (2) as follows:

- a) Costs of killing or emergency slaughter of diseased and suspected animals and safe disposal of their carcasses. Where appropriate, compensation is also provided for safe disposal of their products. In agreement with this, the farmer was compensated for all costs associated with having the BSE positive animal and its whole cohort killed and disposed of in a rendering plant and for all related costs such as examination of the animals, their transport to the rendering plant, etc.

- b) Costs of the animal killed or slaughtered in emergency. For BSE this involved compensation for the value of all animals killed in the cohort identified on the basis of an expert's report. The compensation was provided according to Article 68, paragraph (2) and was based on the price of a healthy bovine animal of the appropriate category that was common in that place at the time of losses incurred.

- d) Cleaning, disinfection, disinsection and deratisation of the holdings and of the equipment on the holdings.

- e) Losses evidently caused by the impossibility to obtain products from the animals involved in the period of implementation of Emergency Veterinary Measures. For milking cows lost in relation to BSE, compensations were provided for the potential highest milk yield according to the "Milk Yield Assessment", and calculated as described in the Methods.

Article 70 describes the procedure of applying for loss compensation and the legal conditions to be met. The compensation is provided by the Ministry of Finance of the Czech Republic from the state budget, if not stated otherwise in the EU Regulations. The application can be submitted on the following day at the earliest and by 6 weeks of the day of animal killing or slaughter at the latest. To assess whether the conditions for loss compensations were met and to what extent compensation should be provided, the Ministry of Agriculture will consult the relevant Regional Veterinary Administration office. If the application is not submitted in due time, the compensation claim will be forfeited. If preventive, control and eradication measures are in force for a long time, farmers can get some advanced payment according to Article 67, paragraph (2).

Part II. Economic evaluation of loss compensations

The reimbursements for the period of 2001-2007 were itemised, analysed and finally summarised. Based on item analysis, the results for 2001 and 2002 are distinguished from the 2003/2007 period, because of the different sources for indemnity policy in BSE examination and emergency measures items (Tables 1 and 2). All compensations for the whole evaluated period are presented in Table 3. 

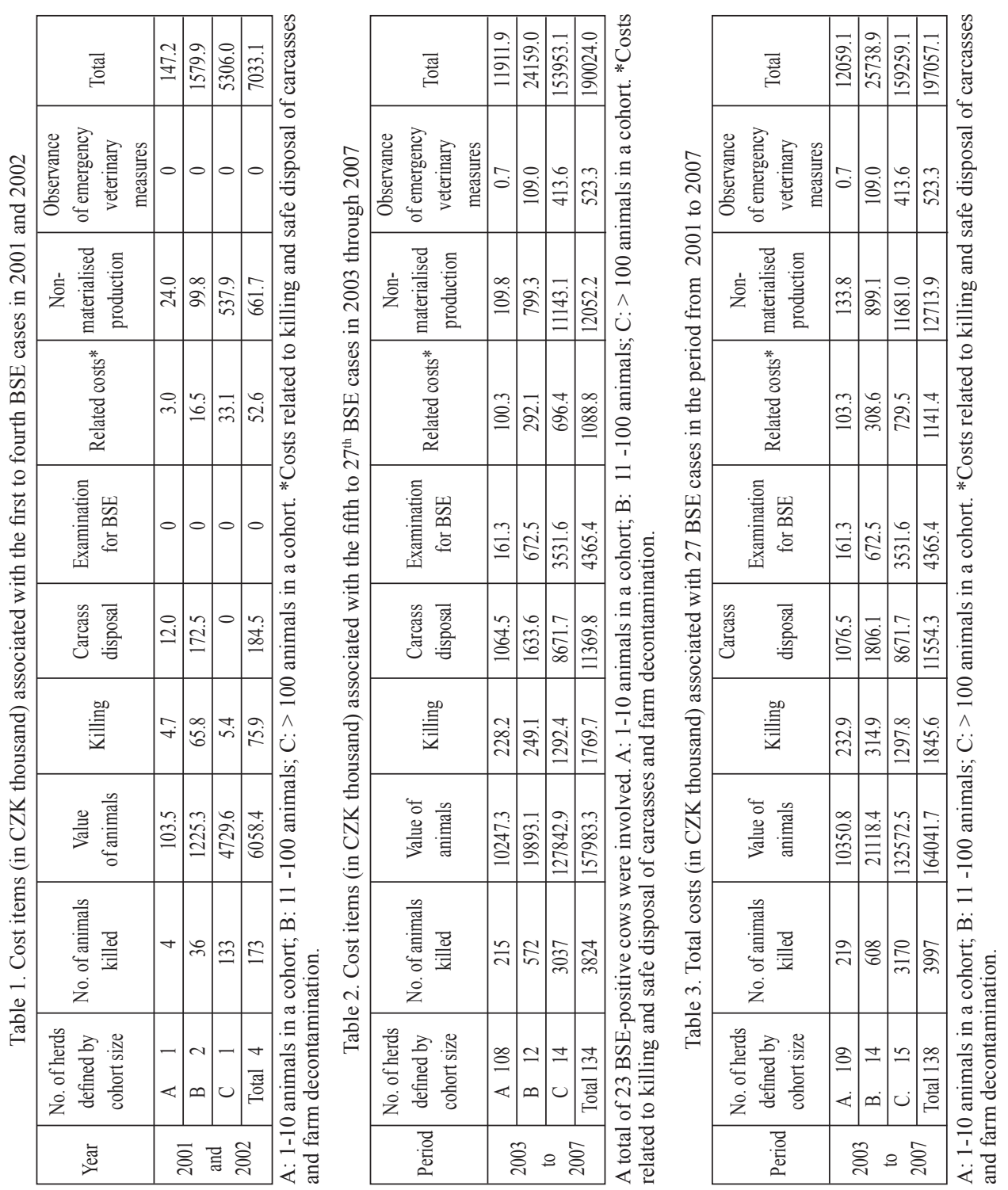

From 2001, when the first two BSE cases were recorded, till the end of 2002, 173 animals were killed in relation to four BSE-positive cows, and the total cost of compensations amounted to CZK 7,033 thousand. In that period, the costs of examination for BSE and those spent to implement the Emergency Veterinary Measures were reimbursed directly from the part of state budget known as state contract (Chapter "General Treasury Administration") and therefore were not reported by the Ministry of Agriculture amongst the costs related to BSE in 2001 and 2002 (Table 1).

In the period from 2003 to 2007, a total of 23 new, BSE-positive animals were detected. The number of cohorts is not in agreement with the total of 134 herds affected, as shown in Table 2. This is because there were instances when an animal from the original cohort 
was transferred or sold to another herd and, subsequently, its keeper having to comply with the Emergency Veterinary Measures had this cow killed; thus one cow was reported in association with two or more herds. The total cost compensations were CZK 190,024 thousand (Table 2).

Table 3 shows compensation for all costs spent in relation to BSE between 2001 and 2007. A total of 27 animals tested BSE-positive and, consequently, 3,997 animals coming from 138 herds were killed due to constitution of cohorts. The total of compensations in this period reached CZK 197,057 thousand. The average occurrence was 3.86 BSE-positive animals per year and the average costs per animal were CZK 7.3 million (Table 3).

\section{Discussion}

Although early and stringent veterinary precautions were adopted, mainly the ban on feeding meat and bone meal (MBM) to cattle in 1991, the first case of BSE in the Czech Republic was detected in 2001. The most probable cause was indirect contamination of cattle feed with imported MBM or with MBM intended for feeding pigs and poultry and allowed for use until 2003 (Semerád 2007). In the period from February 1, 2001 to November 30, 2007, a total of 27 BSE-positive cases were identified by the active monitoring for BSE involving 1 194,743 cows. The detection was so effective thanks to well co-ordinated laboratory diagnostic procedures carried out in the laboratories of the State Veterinary Institutes in Prague, Jihlava and Olomouc.

When a BSE-positive animal is diagnosed in a herd, a cohort of animals to be killed and destroyed is assembled. This is organized by experts of the relevant Regional Veterinary Administration (RVA) office who, in co-operation with the farmer and on the basis of the Central Registry of Farm Animals, locate animals that for any reason were moved away from the farm. The transport of cohort animals to the appropriate rendering farm is the farmer's responsibility, and killing of the animals is organized and controlled by the Veterinary Administration Officers. The act of killing is performed at the specialised rendering plant by the workers of RVA Emergency Disease Control Centres of either Brno or Hradec Králové.

To reduce the economic impact of BSE on farmers, legal means have been established to reimburse farmers for the losses both direct and related. The latter involve costs of examination for BSE, transport of animals to a rendering plant, their killing and safe disposal of their carcasses, and cleaning and disinfection of the holding and its equipment, though this procedure is questionable because BSE is not a truly contagious disease. In addition, the farmer is reimbursed for losses due to non-materialised production. However, all these compensations cannot completely cover the costs incurred in relation to BSE.

In the first place, producer-consumer relations, usually taking a long time to establish, are destroyed and the return to market is difficult; then, large costs are necessary to build up the herd again. These costs are difficult to calculate and their compensation cannot be claimed because they are not treated by legislation. A BSE incident is also associated with several adverse consequences, such as a loss of job in an agricultural enterprise, which may have a deep impact on rural populations. The ensuing problems in the broadest sense of the word can partly be eased by commercial insurance policy. The past experience showed that most of the farmers were insured. Any payment of insurance benefit has no effect on the amount of cost compensation based on the Veterinary Act. Since a farmer-insurance company relationship is a business one, it was not possible to find out information on benefit payments and include it in this study.

At slaughterhouses, with examination for BSE and in the interest of consumer health, as specified by EC Regulation No. 9992001 of the European Parliament and of the Council, so-called specified risk material (SRM) is collected and removed from the food chain. Because SRM is included in slaughter waste (it is processed in rendering plants only), its 
value is neither recorded nor considered in relation to cost compensations. In one study only (Muth et al. 2005) SRM has been valued at \$ 7 per cow.

Owing to early and good quality legislation, the farmers with BSE on their premises could be reimbursed as early as the first year of disease detection (first and second cases). By May 2007 all compensations including the last three cases of 2006 (24 th $\left.26^{\text {th }}\right)$ were received by the farmers. The compensation for the last case of September 11, 2007 was paid in December 2007.

The total amount of compensation paid was CZK 5.5 million in 2001, 1.6 CZK million in 2002, CZK 47.0 million in 2003, CZK 39.8 million in 2004, CZK 91.9 million in 2005, and CZK 11.1 million in 2006. In 2007 it was only CZK 169.5 thousand, because the $27^{\text {th }}$ case was an eleven-year-old cow whose cohort included only three animals due to gradual slaughter of the other cows. This implies that the animals reared or fed together with this BSE-positive cow were all negative on examination for BSE at slaughter.

The total costs associated with the BSE occurrence in the Czech Republic amounted to CZK 197.1 million. The average number of cattle lost to death due to BSE every year was 3.86 animals and the average costs per animal were CZK 7.3 million.

Of these, $83.3 \%$ (CZK 164.0 million) were compensations for the value of killed animals, 9.7\% (CZK 18.9 million) for the related costs, i.e., killing, safe disposal of carcasses and examination for BSE, and $6.9 \%$ (CZK 13.6 million) for the losses due to non-materialised production.

To ease the negative economic impacts of BSE, the EU provides financial support for all member states. For instance, in 2005 the Czech Republic received $€ 1,640$ thousand for active monitoring and $€ 2,500$ thousand for eradication (EU-DG-SANCO E. 2, 2006).

It is interesting that the amounts of reimbursement presented in the international literature are reported only as total costs per certain period, including data from Great Britain, that was the most affected. The calculation of cost compensations is based on tables prepared in advance in which, for each age cattle category, the amount of compensation is given without any respect to each animal's actual productivity (Defra 2007). A British Government study has reported that the total net cost of the BSE crisis to the Exchequer by the end of the fiscal year 2001/2002 reached $\$ 4.2$ billion, to which the EU contributed with $£ 487$ million, which is $11.6 \%$ (Brinkle 2002). It is evident that this high sum of money was relevant to the exceptionally high number of BSE-positive cows that had exceeded 187,000 animals by that fiscal year. This sum also included $£ 720$ million to compensate for the loss of markets in the EU countries, because the European Commission banned beef export in March 1996 (in the USA the import of British beef was banned in late 1980's). Beef production accounts for about $0.5 \%$ of the British gross domestic product and the British beef industry has over 130,000 employees.

With a decrease in beef meat prices, prices of all other kinds of meat increased in Great Britain. This chiefly concerned poultry and lamb meat, which increased in price approximately by $5 \%$, with pork price remaining generally unchanged (Leeming and Turner 2004).

In Northern Ireland, the beef producing industry employs over 5,000 workers and additional 600,000 are employed in related industrial branches (Caskie et al. 1998). Thus, the rate of employment in this industry has a deep social impact. The costs of re-qualification for workers who had lost their jobs due to reduced beef production were estimated to be $7.9 \%$ of all costs related to the BSE crisis (Muth et al. 2005).

In 2003, the first BSE cases were reported in North America, namely, on May 20 in the Canadian province Alberta and then on December 23 in Washington State, USA. Both American and Canadian economic studies describe four major effects of the BSE crisis on national economies: effect on the sector, effect on the company, effect on the market and overall social effect on the population (Muth et al. 2005). 
Before BSE announcement, the USA exported beef to 53 countries, with Japan, Mexico, South Korea and Canada accounting for $91 \%$ of the US export. In 2003 beef exports were valued at $\$ 3.95$ billion and after the ban was imposed, they dropped by $82 \%$ from year to year. During the first week after BSE discovery, the price of beef in the USA fell by $16 \%$ (Coffey et al. 2005). In the following year the US domestic beef demand decreased by about $15 \%$ and the whole beef production industry lost over $\$ 2$ billion (Yeboah et al. 2006).

Similarly, Canada is one of the largest beef and cattle exporters. It exports over $50 \%$ of its beef production and, of this volume, $40 \%$ is exported to the USA. After the first BSE incident in 2003, the fall in price was even more dramatic than in the USA. In eight weeks the beef price declined from \$ 107 to near \$ 30 per hundredweight (approximately $45 \mathrm{~kg}$ ), i.e., by $72 \%$. For 2004 the prices were estimated to increase and became stable, trading in the $\$ 75$ to $\$ 83$ range prior to the announcement (Francl 2003). In the USA, for instance, each fall in price by $\$ 10$ per hundredweight results in revenues reduced by $\$ 3.5$ billion for the whole industry. In 2004, the testing of animals for BSE at abattoirs cost American economy $\$ 221$ million, which is approximately $\$ 12$ to $\$ 15$ per animal (Blach 2004).

In addition to the decline in beef prices and beef consumption, the BSE crisis was accompanied by a number of other costs. The American Food Safety Inspection Service (FSIS) has reported that the costs of a single instruction course for employees of large cattle rearing companies ranged, in proportion to company size, from $\$ 14,000$ to $\$ 100,000$. The implementation of safety and health FSIS regulations in 2004 were figured out to be almost \$ 65 million and the total costs the American companies incurred due to BSE exceeded $\$ 200$ million. Because of these increased costs, company investments decreased on average by $\$ 700,000$ (Coffey et al. 2005)

The Governments of Canada and Alberta offered Alberta cattle producers BSE directed Economic Aid Programs at a total of more than $\$ 1$ billion (Usherwood 2004). These included \$ 460 million National BSE Recovery Program for producers with cattle on feed; \$ 65 million Alberta Feeder Cattle Program; \$ 67 million Alberta Feeder Competitive Market Adjustment Program; \$ 100 million Alberta Steer and Heifer Transition Program; a \$ 125 million program for culled cattle from the Government of Alberta; and \$200 million national Cull Cow and Bull Program.

In conclusion, it is not possible to provide a reliable comparison of the costs associated with BSE, because the currency value is different in each of the countries discussed in this paper. However, the data available suggests that the compensations for BSE-related costs paid to farmers in the Czech Republic were proportional to those in the USA or Canada.

The analysis of all costs shows that the compensations paid to farmers were not sufficient to cover the whole range of costs related to BSE because, for instance, the loss of a herd built up for many years or break-up of producer-consumer relationships cannot be compensated for.

Early adoption and long-term implementation of emergency veterinary measures resulted in an anticipated fall in BSE occurrence in the last two years, to which consumers responded with increased beef consumption.

\section{Vyplácení náhrad při výskytu bovinní spongiformní encefalopatie v České republice v letech 2001 až 2007}

Na základě právní úpravy jsou v České republice chovatelům při výskytu BSE poskytovány náhrady za náklady spojené s diagnostikou onemocnění, s utracením zvírat, s jejich neškodným odstraněním a s asanací, dále pak náhrady za utracená zvířata a za nerealizovanou produkci. Za dobu výskytu nemoci od roku 2001 bylo v České republice vyšetřeno 1194743 krav a do konce roku 2007 bylo prokázáno 27 případů BSE a v souvislosti s nimi utraceno a neškodně odstraněno 3997 krav. Ke snížení negativních ekonomických dopadů do zemědělské výroby 
jsou vybrané druhy nákladů chovatelům hrazeny Ministerstvem financí ČR z rozpočtové kapitoly „Všeobecná pokladní správa“. Náklady na vyšetření na BSE, utracení a asanaci dosáhly 18,9 mil. Kč (9,7 \% z celkových nákladů), za utracená zvírata činila výše vyplacených náhrad téměř 164,0 mil. Kč (83,3 \%) a náhrady za nerealizovanou produkci dosáhly téměř 13,6 mil. Kč (6,9\%). Spolu s dalšími dodatečnými náklady činila celková výše vyplacených náhrad za celé období výskytu nemoci v ČR téměř 197 mil. Kč. Dosažené výsledky jsou diskutovány s nepř́liš četnými informacemi o nákladech vyvolaných nemocí BSE v zahraničí. Tyto zdroje však informují pouze o celkových nákladech spojených s výskytem BSE a nikoliv o jednotlivých nákladových položkách, kterými jsou podnikatelé zatíženi.

\section{Acknowledgement}

The work was supported by the Research Project of the Ministry of Education, Youth and Sports No.6215712403.

\section{References}

ANONYMOUS 1999: Zákon č. 166/1999 Sb. o veterinární péči a o změně některých souvisejících zákonů [Act No. 166/1999 Coll. on veterinary care]

ANONYMOUS 2000a: Zákon č. 218/2000 Sb. o rozpočtových pravidlech [Act No. 218/2000 Coll. on fiscal rules]

ANONYMOUS 2000b: Zákon č. 240/2000 Sb. o krizovém řízení [Act No. 240/2000 Coll. on emergency regulations].

ANONYMOUS 2003: Vyhláška č. 299/2003 Sb. o opatřeních pro předcházení a zdolávání nákaz a nemocí přenosných ze zviŕat na člověka [Regulation No. 299/2003 Coll. on prevention, control and regulation of animal diseases transmissible to man]

BLACH R 2004: Economic impact of BSE on the U.S. beef industry. Cattle-Fax, Colorado, USA

BRINKLE J 2002: Impact of BSE on the UK economy. National audit office, NC, USA

CASKIE P, MOSS JE, DAVIS J 1998: The beginning of the end or the end of the beginning for the BSE crisis? Food Policy 23: 231-240

COFFEY B, MINTERT J, FOX S, SCHROEDER T, VALENTIN L 2005: The economic impact of BSE on the U.S. beef industry. The Kansas Department of Agriculture, USA, p.64

DEFRA UK 2007: Compensation for bovine TB, BSE, brucellosis and enzootic bovine leukosis. Inform Bull Ref.: 238/07

DUBEN J 2007: Tisková zpráva SVS ČR. Státní veterinární správa ČR, SVA [Press conference report. State Veterinary Administration of the Czech Republic]

EU-DG SANCO E 2006: Hygiene and control measures. Annual activity report, pp. $42-43$

FRANCL T 2003: The economic impact of BSE. American Farm Bureau Federation, USA

LEEMING J, TURNER P 2004: The BSE crisis and the price of red meat in the UK. Appl Econ 36: 1825-1829

MAIER H 2001: Rough estimation of economic impact of present BSE-illness of cows in Germany. IAOS Satelite Meeting on Statistics for the Information Society, Tokyo, Japan

MELOUN V 2006: Výskyt BSE v České republice do roku 2006. Písemná atestační práce k atestaci II. stupně [BSE occurrence in the Czech Republic till 2006. Dissertation thesis]. Státní veterinární správa ČR, Brno, 118 p.

MUTH MK, BEACH R, KARNS S, VIATOR C 2005: Economic impact analysis: BSE rulemaking. Final report, contract No. 53-3A94-03-12, RTI International

POSPÍŠIL R, HOLEJŠOVSKÝ J, BARDOŇ J 2007: Zásady a forma náhrad vyplácených při výskytu bovinní spongiformní encefalopatie [The main principles of compensations to breeders with the occurrence of BSE in breeding cattle and with regards to thein disbursement]. Veterinářství 7: 459-461

POSPÍŠIL R 2008: Hlavní zásady a struktura náhrad poskytovaných chovatelům s výskytem bovinní spongiformní encefalopatie $\mathrm{v}$ chovech skotu [Majority of compensations to breeders with BSE occurrence in breeding cattle]. Acta Univ Agric Silvic Mendel Brun (In press). SAKSÚN J 2007: Informace Ministerstva zemědělství ČR k výskytu BSE v ČR [Ministry of Agriculture Information on BSE occurrence in the Czech Republic], MZe $\breve{C R}$, Praha

SEMERÁD Z 2007: Osobní sdělení [Personal communication]. SVS ČR, Praha

USHERWOOD D 2004: BSE in Canada, economic impact and possible recovery strategy. Ag and Food Committee of the Calgary Chamber of Commerce, Canada

YEBOAH OA, THOMSON H, OFORI-BOADU V 2006: BSE and the US economy: adjustments in a specific factors model. American Farm Bureau Federation, USA

WALTON TE 2000: The impact of diseases on the importation of animals and animal products. Ann N Y Acad Sci 916: $36-40$

Foot-note: Shortly after submission of the manuscript to the Editorial Office of Acta Veterinaria Brno, BSE was detected in a ten-year-old cow on 19 December 2007. This is the $28^{\text {th }}$ case and its cohort included 25 animals. 